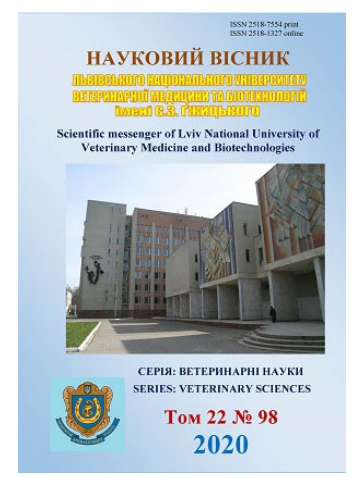

\author{
Науковий вісник Дьвівського націонадьного університету \\ ветеринарної медицини та біотехнологій імені С.3. Гжицького. \\ Серія: Ветеринарні науки \\ Scientific Messenger of Lviv National University \\ of Veterinary Medicine and Biotechnologies. \\ Series: Veterinary sciences
}

UDC 636.7:616.99:595.775.1

\title{
Age dynamics of infestation of dogs Ctenocephalides spp.
}

\author{
V. O. Yevstafieva, K. O. Horb \\ Poltava State Agrarian Academy, Poltava, Ukraine
}

Article info

Received 01.04.2020

Received in revised form 04.05 .2020

Accepted 05.05.2020

Poltava State Agrarian Academy, Skovorody Str., 1/3, Poltava, 36003, Ukraine.

Tel.: +38-050-183-78-78

E-mail:evstva@ukr.net
Yevstafieva, V. O., \& Horb, K. O. (2020). Age dynamics of infestation of dogs Ctenocephalides spp. Scientific Messenger of Lviv National University of Veterinary Medicine and Biotechnologies. Series: Veterinary sciences, 22(98), 84-87. doi: 10.32718/nvlvet9815

The ectoparasites Ctenocephalides felis and Ctenocephalides canis are distributed worldwide and are the most common species of fleas that parasitize domestic carnivores. As active vectors of infectious and invasive diseases, fleas of the genus Ctenocephalides are of great epidemiological importance. Intensive growth of the number of dogs, violation of sanitary and hygienic conditions of their keeping, especially in large cities, as well as global warming significantly affect the epizootic situation regarding ctenocephalidosis. The aim of the work was to study the features of age susceptibility of domestic dogs in the city of Poltava (Ukraine) to Ctenocephalides spp. Indicators of infestation of animals with the causative agent of ctenocephalidosis depending on their age and housing conditions were determined. Studies have shown that dogs of any age are prone to flea infestation. Ctenocephalidosis is diagnosed in animals of all ages. At the same time, the age dynamics of defeat of dogs by parasitic insects under different conditions of their keeping differed significantly. The average extensity and intensity of the invasion was lower in animals kept in apartments $(26.47 \%, 10.82$ specimens/head) compared to animals kept in the private sector $(76.21 \%$, 22.71 specimens/head). The highest rates of flea infestation of the genus Ctenocephalides were found in dogs aged one to six years (37.10-45.45\%; 10.45-15.91 specimens/head) - for housing, as well as in young animals up to 12 month of age (84.03-90.36\%; 22.78-32.56 specimens/head) - for aviary maintenance. Less infested were dogs under 6 months of age (11.26\%; 5.43 specimens/head) and older 6-year-olds (16.28\%; 8.54 specimens/head) - for housing, as well as dogs aged one to six years (53.54-75.38\%; 11.63-20.24 specimens/head) - for aviary keeping. The results obtained regarding the age dynamics of infestation of domestic dogs with fleas of the genus Ctenocephalides can be taken into account when carrying out measures to control and prevent ctenocephalidosis in dogs under different conditions of their content.

Key words: ctenocephalidosis, dogs, fleas, age dynamics, invasiveness indicators.

\section{Вікова динаміка інвазованості собак Ctenocephalides spp.}

\author{
В. О. Євстаф’єва, К. О. Горб
}

Полтавська державна аграрна академія, м. Полтава, Украӥна

Eктопаразити Ctenocephalides felis $і$ Ctenосерhalides canis розповсюджені по всьому світу та є найбільи потиреними видами бліх, що паразитують у домашніх м'ясоїдних тварин. Як активні переносники збудників інфекиійних та інвазійних захворювань блохи роду Ctепосерhalides мають важливе епідеміологічне значення. Інтенсивне зростання чисельності собак, порушення санітарно-гігієнічних умов їх утримання, особливо у великих містах, а також глобальне потепління клімату істотно впливають на епізоотичну ситуаиію щодо ктеноцефальозу. Метою роботи було вивчити особливості вікової сприйнятливості домашніх собак на території міста Полтава (Україна) до Сtепосерhalides spp. Визначено показники інвазованості тварин збудником ктеноцефальозу залежно від їх віку та умов утримання. Проведеними дослідженнями встановлено, що до зараження блохами схильні собаки будь-якого віку. Ктеноцефальоз діагностовано у тварин всіх вікових груп. Водночас, вікова динаміка ураження собак паразитичними комахами за різних умов їх утримання значно відрізнялася. Середня екстенсивність та інтенсивність інвазії виявилася нижчою у тварин, яких утримували у квартирах $(26,47 \%, 10,82$ екз./гол.) порівняно з тваринами, яких утримували у приватному секторі (76,21\%, 22,71 екз./гол.). Найбільші показники інвазованості блохами роду Сtепосерhаlides виявлено у собак віком від одного 
до шести років (37,10-45,45\%; 10,45-15,91 екз./гол.) - за квартирного утримання, а також у молодняку до 12-місячного віку (84,03-90,36\%; 22,78-32,56 екз.гол.) - за вольєрного утримання. Менш інвазованими були собаки до 6-місячного віку (11,26 \%; 5,43 екз./гол.) і стариі 6-річного віку (16,28\%; 8,54 екз./гол.) - за квартирного утримання, а також собаки віком від одного до шести років (53,54-75,38\%; 11,63-20,24 екз.гол.) - за вольєрного утримання. Отримані результати відносно вікової динаміки інвазованості домашніх собак блохами роду Ctепосерhalides можливо враховувати при проведенні заходів щзодо боротьби та профілактики ктеночефальозу собак за різних умов їх утримання.

Ключові слова: ктеноцефальоз, собаки, блохи, вікова динаміка, показники інвазованості.

Вступ

Результати досліджень багатьох науковців свідчать, що у домашніх м'ясоїдних тварин частіше паразитують два види бліх - Ctenocephalides felis i Ctenocephalides canis (Chesney, 1995; Rinaldi et al., 2007; Hernández-Valdivia et al., 2011).

Серед C. felis виділяють 4 підвиди, які поширені в усьому світі та викликають у собак і котів ектопаразитарні захворювання. Так підвиди C. felis damarensis і C.felis strongylus зареєстровано в Африці, C.felis orientis - в Південно-Східній Азії і Західній Індії. Вони можуть нападати на велику і дрібну рогату худобу, людину, але паразитують вони здебільшого, особливо перші два підвиди, на диких і домашніх м'ясоїдних тваринах (Dryden \& Prestwood, 1993; Үао et al., 2006; 2010; Lawrence et al., 2019). Водночас, найбільш розповсюдженим підвидом бліх, який паразитує у різних видів диких та домашніх тварин $є$ C. felis felis. Загалом паразитичними комахами C. felis можуть заражатися більше 50 видів ссавців і птахів (Bossard et al., 1998; Thilkan \& Karunanithi, 2001; Linardi \& Santos, 2012; Shakya et al., 2019). Даний вид бліх швидко пристосовується до різних умов існування, і хоча, його початковим хазяїном був кіт свійський (Felis catus), C.felis може паразитувати і на інших видах тварин, внаслідок пристосування і відсутності специфічності. Так при паразитуванні у собак характерного для них виду бліх C. canis, блохи виду C. felis часто його витісняють. На думку науковців, це пов'язано з тим, що C. canis більш специфічний щодо хазяїна і більш вибагливий до умов існування, ніж C.felis (Linardi \& Nagem, 1973). Проте, в таких країнах як Корея, Туреччина, Греція C. canis залишається домінуючим видом (Aldemir, 2007; Ahn et al., 2018).

Науковцями виявлено, що у Великобританії найбільш поширеним видом бліх $є$ C. felis, a C. canis зареєстровано тільки у безпритульних тварин та собак, що утримуються в сільській місцевості. Водночас, на території Франції 99 \% обстежених домашніх котів та $89 \%$ собак виявилися інвазованими блохами виду C.felis. Зараження собак C. canis виявляли тільки в $10 \%$ випадків (Beugnet et al., 2004). Інші автори свідчать, що екстенсивність інвазії собак C. felis становила на території США $90 \%$, Німеччини - $57 \%$ (Liebisch \& Reimann, 2000).

3 огляду на значне поширення бліх серед популяції домашніх собак і котів у різних країнах світу та їх важливе епідеміологічне значення, метою роботи було вивчити особливості вікової сприйнятливості домашніх собак на території міста Полтава (Україна) до Ctenocephalides spp.

\section{Матеріал і методи досліджень}

Роботу виконували упродовж 2017-2020 pр. на базі лабораторії кафедри паразитології та ветеринарносанітарної експертизи Полтавської державної аграрної академії та в умовах ветеринарного сервісу "Vetexpert" (м. Полтава). Всього досліджено 3171 собак різних вікових груп, а саме: до 6 міс., 612 міс., 1-3 роки, 3-6 років. Старші 6 років за різних умов їх утримання (квартирне та вол'єрне).

Виділення бліх 3 тіла тварин проводили шляхом розчісування їх пластиковим дрібнозубним спеціальним гребінцем впродовж 10 хвилин. Зібраних комах фіксували у $70 \%$ етиловому спирті. Ідентифікацію видів виділених паразитичних комах встановлювали при мікроскопії за морфологічними таксономічними ознаками згідно визначника (Wall \& Shearer, 2001). Розраховували екстенсивність інвазії (EI, \%) та інтенсивність інвазії (II, екз./гол.).

Математичний аналіз отриманих даних проводили 3 використанням пакету прикладних програм Microsoft "EXCEL". Розраховували стандартну похибку середнього (m) і середні значення (M).

\section{Результати та їх обговорення}

Проведеними дослідженнями встановлено, що до інвазування блохами схильні собаки будь-якого віку і ктеноцефальоз діагностовано у тварин всіх вікових груп. Середня екстенсивність та інтенсивність інвазії виявилася нижчою у тварин, яких утримували у квартирах $(26,47 \%, 10,82 \pm 0,29$ екз./гол.) порівняно 3 тваринами, яких утримували у приватному секторі (76,21\%, 22,71 $\pm 0,64$ екз./гол.). Водночас, вікова динаміка ураження собак паразитичними комахами за різних умов їх утримання значно відрізнялася. (табл. 1).

Найбільші показники екстенсивності інвазії за квартирного утримання собак виявлено у молодняка віком від одного до шести років (37,10-45,45\%). Менш ураженими були молоді тварини віком від 6 до 12 місяців, ЕІ становила 27,30 \%. Найменш інвазованими були цуценята до 6-місячного віку (ЕI 11,26 \%) і собаки старші 6-річного віку (EI - 16,28 \%).

За вольєрного утримання собак найбільш ураженим блохами виявився молодняк до 12-місячного віку, ЕI коливалася в межах від 84,03 до 90,36 \%. В подальшому, 3 віком тварин, екстенсивність інвазії поступово знижувалася (табл. 2). 
Таблиця 1

Показники екстенсивності інвазії собак Ctenocephalides spp. за квартирного утримання

\begin{tabular}{lccc}
\hline \multicolumn{1}{c}{ Вікова група собак } & Досліджено тварин & Інвазовано тварин & EI, \% \\
\hline Молодняк до 6 міс. & 373 & 42 & 11,26 \\
Молодняк 6-12 міс. & 315 & 86 & 27,30 \\
Собаки 1-3-річного віку & 319 & 145 & 45,45 \\
Собаки 3-6-річного віку & 310 & 115 & 37,10 \\
Собаки старше 6- річного віку & 387 & 63 & 16,28 \\
Всього & 1704 & 451 & 26,47 \\
\hline
\end{tabular}

Таблиця 2

Показники екстенсивності інвазії собак Ctenocephalides spp. за вольєрного утримання

\begin{tabular}{lccc}
\hline \multicolumn{1}{c}{ Вікова група собак } & Досліджено тварин & Інвазовано тварин & $\mathrm{EI}, \%$ \\
\hline Молодняк до 6 міс. & 363 & 328 & 90,36 \\
Молодняк 6-12 міс. & 313 & 263 & 84,03 \\
Собаки 1-3-річного віку & 273 & 192 & 70,33 \\
Собаки 3-6-річного віку & 254 & 136 & 53,54 \\
Собаки старше 6- річного віку & 264 & 199 & 75,38 \\
Всього & 1467 & 1118 & 76,21 \\
\hline
\end{tabular}

Так у собак віком 1-3 роки екстенсивність інвазії становила 70,33 \%, у собак віком 3-6 років - 53,54\%. Водночас, у собак старших 6-річного віку ступінь інвазованості Ctenocephalides spp. незначно зростає i дорівнює 75,38 \%.

Показники інтенсивності інвазї у собак різних вікових груп, також, залежали від способу утримання (рис.).

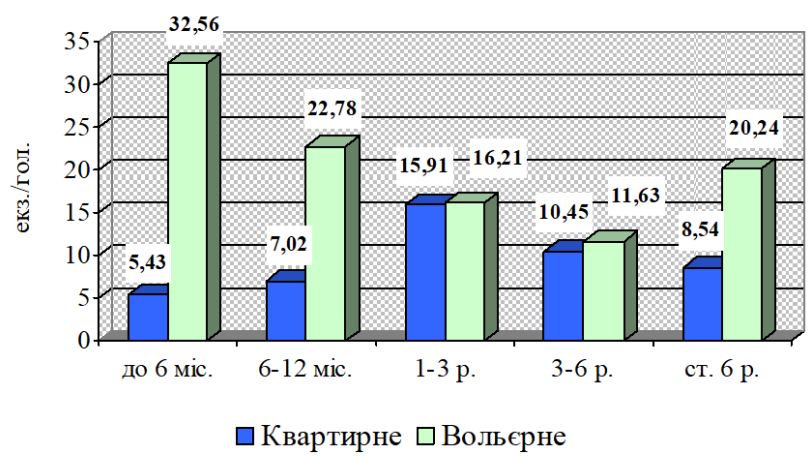

Рис. 1. Показники інтенсивності інвазії собак

Ctenocephalides spp. залежно від умов утримання

За квартирного утримання собак найбільші показники II виявлено у тварин віком від одного до шести років (від 10,45 $\pm 0,43$ до $15,91 \pm 0,47$ екз./гол.), а за вольєрного утримання - у молодняку до 12-місячного віку (від 22,78 $\pm 0,62$ до 32,56 \pm 0,72 екз./гол.). Менш інвазованими були собаки віком до 12 місяців (II від $5,43 \pm 0,70$ до 7,02 \pm 0,40 екз./гол.) і старші 6-річного віку $(8,54 \pm 0,59$ екз./гол.) - за квартирного утримання, а також собаки віком від одного до шести років (II від 11,63 \pm 0,40 до 20,24 \pm 0,66 екз./гол.) - за вольєрного утримання.

Згідно літературних джерел, ктеноцефальоз домашніх собак $€$ значно поширеною інвазією у всьому світі, збудником якої $\epsilon$ ектопаразити роду Ctenocephalides (Liebisch \& Reimann, 2000; Beugnet et al., 2004). В Україні питання щодо епізоотологічних особливостей опрацьовані фрагментарно і описані лише в окремих працях (Semenko \& Kurinec', 2011). Тому, актуальним $є$ вивчення сприйнятливості собак різних вікових груп за різних умов їх утримання до збудника ктеноцефальозу на території України.

Проведеними дослідженнями встановлено, що за різних умов утримання собак вікова динаміка ктеноцефальозу значно відрізняється. Так більш благополучними виявилися тварини, що утримувалися у квартирах порівняно з собаками, що утримувалися у приватному секторі. Причому за квартирного утримання, з віком собак показники інвазованості блохами поступово зростають, що на нашу думку пов'язане 3 більш ретельним доглядом за молодими тваринами, проведенням інсектицидних обробок. За вольєрного утримання собак, навпаки, з їх віком показники екстенсивності та інтенсивності інвазії знижуються, що свідчить про формування більш несприйнятливих умов для живлення паразитів (потовщення та огрубіння шкіри, віковий імунітет тощо). Схожі дані отримані авторами, які встановлювали максимальну зараженість собак блохами у віці 7-12 міс., яка з віком тварин знижувалася $3 \quad 44,4$ до $19,1 \%$ (Prokopenkova, 2005).

Отримані результати відносно вікової динаміки інвазованості домашніх собак блохами роду Ctenocephalides можливо враховувати при проведенні заходів щодо боротьби та профілактики ктеноцефальозу собак за різних умов їх утримання.

\section{Висновки}

Вікова динаміка ктеноцефальозу домашніх собак на території міста Полтава, Україна характеризується більшою ураженістю тварин у віці від одного до шести років за квартирного утримання, де екстенсивність інвазії може досягати 45,45 \%. Водночас, за вольєрного утримання максимальні показники інвазованості виявлено у молодняку до 12-місячного віку, де екстенсивність інвазії досягає 90,36 \%. 
Перспективи подальиих досліджень. Проведені дослідження обумовлюють необхідність встановлення інсектицидної дії сучасних хімічних засобів у боротьбі з ктеноцефальозом.

\section{References}

Ahn, K. S., Huh, S. E., Seol, S. W., Kim, H. J., Suh, K. H., \& Shin, S. (2018). Ctenocephalides canis is the dominant flea species of dogs in the Republic of Korea. Parasites \& Vectors, 11(1), 196. doi: 10.1186/s13071-018-2769-9.

Aldemir, O. S. (2007). Epidemiological study of ectoparasites in dogs from Erzurum region in Turkey. Revue de Médecine Vétérinaire, 158, 148-151.

Beugnet, F., Porphyre, T., Sabatier, P., \& ChalvetMonfray, K. (2004). Use of a mathematical model to study the dynamics of Ctenocephalides felis populations in the home environment and the impact of various control measures. Parasite, 11(4), 387-399. doi: 10.1051/parasite/2004114387.

Bossard, R. L., Hinkle, N. C., \& Rust, M. K., 1998: Review of insecticide resistance in cat fleas (Siphonaptera: Pulicidae). Journal of Medical Entomology, 35(4), 415422. doi: 10.1093/jmedent/35.4.415.

Chesney, C. J. (1995). Species of flea found on cats and dogs in south west England: further evidence of their polyxenous state and implications for flea control. Veterinary Record, 136(14), 356-358. doi: 10.1136/vr.136.14.356.

Dryden, M. W., \& Prestwood, A. K. (1993). Successful flea control. ompendium on Continuing Education for the Practising Veterinarian, 15, 821-831.

Hernández-Valdivia, E., Cruz-Vázquez, C., OrtizMartínez, R., Valdivia-Flores, A., \& QuinteroMartínez, M. T. (2011). Presence of Ctenocephalides canis (Curtis) and Ctenocephalides felis (Bouché) infesting dogs in the city of Aguascalientes, México. Journal of Parasitology, 97(6), 1017-1019. doi: 10.1645/GE-2701.1.

Lawrence, A. L., Webb, C. E., Clark, N. J., Halajian, A., Mihalca, A. D., Miret, J., D'Amico, G., Brown, G., Kumsa, B., Modry, D., \& Slapeta, J. (2019). Out-ofAfrica, human-mediated dispersal of the common cat flea, Ctenocephalides felis: The hitchhiker's guide to world domination. International Journal for Parasitology, 49(5), 321-336. doi: 10.1016/j.ijpara.2019.01.001.

Liebisch, A., \& Reimann, U. (2000). The efficacy of imidacloprid against flea infestation on dogs compared with three other topical preparations. Canine Practice, 25(2), 8-11.
Linardi, P. M., \& Nagem, R. L. (1973). Pulicídeos e outros ectoparasitos de cães de Belo Horizonte e municípios vizinhos. Revista Brasileira de Biologia, 33(4), 529-537.

Linardi, P. M., \& Santos, J. L. (2012). Ctenocephalides felis felis vs. Ctenocephalides canis (Siphonaptera: Pulicidae): some issues in correctly identify these species. Brazilian Journal of Veterinary Parasitology, 21(4), 345-354. doi: 10.1590/s1984-29612012000400002.

Prokopenkova, I. A. (2005). Sezonnaja i vozrastnaja dinamika zarazhennosti sobak i koshek Ctenocephahdes felis, Materialy Vserossijskogo veterinarnogo kongressa i XIII Mezhdunarodnogo Moskovskogo kongressa po boleznjam melkih domashnih zhivotnyh, Moskva (in Russian).

Rinaldi, L., Spera, G., Musella, V., Carbone, S., Veneziano, V., Iori, A., \& Cringoli, G. (2007). A survey of fleas on dogs in southern Italy. Veterinary Parasitology, 148(3-4), 375-378. doi: 10.1016/j.vetpar.2007.06.036.

Semenko, O. V., \& Kurinec', D. M. (2011). Poshyrennja ektoparazytiv sered populjacii' bezprytul'nyh sobak u Kyjevi. Naukovi doaovidi Nacional'nogo universytetu bioresursiv i pryrodokorystuvannja Ukrai'ny, 7(29), 15 (in Ukrainian).

Shakya, M., Sikrodia, R., Parthasarathi, B. C., Jayraw, A. K., Singh, M., Deepak Upadhaya, Fular, A., Bisht, N., \& Kumar, S. (2019). Cat flea (Ctenocephalides felis felis) and Oriental cat flea (Ctenocephalides orientis) infestation as a emerging nuisance to human population. Journal of Entomology and Zoology Studies, 7(3), 190-192. http://www.entomoljournal. com/archives $/$ year $=2019 \&$ vol $=7 \&$ issue $=3 \&$ ArticleId $=5175$.

Thilkan, N. J., \& Karunanithi, K. (2001). Occurrence of Ctenocephalides infestation and their control in small ruminants. Indian Journal of Small Ruminants, 7(2), 89-90.

Wall, R., \& Shearer, D. (2001). Veterinary ectoparasites: biology, pathology and control. 2nd ed. Oxford: Blackwell Science Ltd.

Yao, K. P., Ngoran, K. E., \& Franc, M. (2006). Etude de quelques paramètres écologiques de Ctenocephalides felis strongylus (Jordan, 1925) (Siphonaptera: Pulicidae). Parasite, 13(2), 159-164. doi: 10.1051/parasite/2006132159.

Yao, K. P., N'Goran, K. E., \& Franc, M. (2010). Influence of the temperature on the development of the African cat flea Ctenocephalides felis strongylus (Jordan, 1925) (Siphonaptera: Pulicidae). Parasite, 17(2), 155159. doi: $10.1051 /$ parasite/2010172155. 